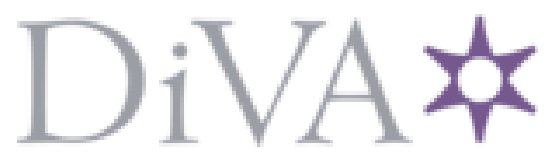

http://www.diva-portal.org

This is the published version of a chapter published in Wounds and wound repair in medieval culture.

Citation for the original published chapter:

Langum, V. (2015)

The wounded surgeon: devotion, compassion and metaphor in medieval England.

In: Larissa Tracy and Kelly DeVries (ed.), Wounds and wound repair in medieval culture (pp.

269-290). Leiden: Brill Academic Publishers

Explorations in Medieval culture

http://dx.doi.org/10.1163/9789004306455_014

N.B. When citing this work, cite the original published chapter.

Permanent link to this version:

http://urn.kb.se/resolve?urn=urn:nbn:se:umu:diva-105349 


\title{
“The Wounded Surgeon": Devotion, Compassion and Metaphor in Medieval England
}

\author{
Virginia Langum
}

In the second of the Four Quartets, T.S. Eliot draws upon a millennium and a half of Christus medicus "Christ the physician" imagery: ${ }^{1}$

The wounded surgeon plies the steel

That questions the distempered part;

Beneath the bleeding hands we feel

The sharp compassion of the healer's art

Resolving the enigma of the fever chart. $^{2}$

The pain and compassion of surgeon and patient are here reciprocal. The "wounded" surgeon operates with "bleeding hands," and the patient "feels" "the sharp compassion" as though it were a material scalpel incising flesh. This interior practice, whether understood as physical dissection or penetrative empathy, parses the external and more abstract "fever chart." Eliot extends the image of physician into a more specific image of surgery.

Surgery, with its unique concurrence of harming and healing, opening and sealing, punishing and curing, generates particular imaginative possibilities as a metaphor in medieval texts, beyond the trope of Christus medicus and general analogies of spiritual and medical healing. In addressing the rise of surgical imagery in Middle English poetry, such as the Siege of Jerusalem and the Pearl-Poet's Cleanness, Jeremy Citrome argues that surgery is more spiritu-

1 John T. McNeill and Helena M. Gamer, Medieval Handbooks of Penance: A Translation of the Principal Libri Poenitentiales and Selections from Related Documents (New York: Columbia University Press, 1938), 44-50; John T. McNeill, "Medicine for Sin as Prescribed in the Penitentials," Church History 1 (1932): 14-26; and Rudolph Arbesmann, "The Concept of Christus Medicus in St. Augustine," Traditio 10 (1954):1-28. See also: Shelley Annette Reid, "The First Dispensation of Christ is Medicinal': Augustine and Roman Medical Culture," (Ph.D. dissertation, University of British Columbia, 2008).

2 T.S. Eliot, Four Quartets (London: Faber and Faber, 2001), 18. 
ally dextrous than medicine as surgery can be both punitive and restorative. ${ }^{3}$ Surgical incision and amputation by the surgeon-priest appear in confessional texts from medieval England. ${ }^{4}$ However, during this same period, the late fourteenth century and fifteenth century, Christus chirurgus "Christ the surgeon" also emerges in religious texts.

Rather than the punitive, surgical model of corrosive purging and excommunicative severing charted by Citrome and others, Christ the surgeon is compassionate. Christ the surgeon incorporates the more traditional and popular meditative aide, Christ's wound, inviting the faithful to meditate on His wound as though their own. Although attained through torture rather than medical intervention, His crucifixion wound becomes a surgical wound when Christ adopts the role of a surgeon to attach the faithful to it. Likewise, the surgical wound of the circumcision serves as a location for compassionate healing by spurring reflection upon the pain and humanity shared by the infant Christ. Placing images of Christ the wounded surgical patient and Christ the surgeon, compactly phrased as Eliot's "wounded surgeon," in dialogue, reveals how surgery generates unique opportunities for compassion in pastoral and devotional texts of late medieval England. Surgery provides a medical understanding of compassion, how the pain of the wound may be felt within another body part, and even felt by another person. These passages - in sermons such as the fifteenth-century Oxford sermon collection Bodley 649 and the fifteenth-century cycle edited as Lollard Sermons, devotional texts such as Nicholas Love's Mirror of the Blessed Life of Jesus Christ and Speculum devotorum, and mystical visions such as the Middle English translation of Bridget of Sweden's Liber celestis and Julian of Norwich's Revelation of Love - align Christ's wounds suffered at the circumcision or the crucifixion with the human wounds of sin, offering a metaphorical and physiological treatment of compassion.

3 Jeremy Citrome, The Surgeon in Medieval English Literature (New York: Palgrave Macmillan, 2006). Cf. Michael Livingston, "The Depth of Six Inches': Prince Hal's Head-Wound at the Battle of Shrewsbury," 215-30; Iain A. MacInnes, "Heads, Shoulders, Knees and Toes: Injury and Death in Anglo-Scottish Combat, c. 1296-c. 1403," 102-27; Carmel Ferragud, "Wounds, Amputations, and Expert Procedures in the City of Valencia in the Early-Fifteenth Century," 233-51; and Timothy May, "Spitting Blood: Medieval Mongol Medical Practices," 175-93; Debby Banham and Christine Voth, "The Diagnosis and Treatment of Wounds in the Old English Medical Collections: Anglo-Saxon Surgery?", 153-74; and Larissa Tracy, "Into the hede, throw the helme and creste': Head Wounds and a Question of Kingship in the Stanzaic Morte Arthur," $496-518$, in this volume.

4 Virginia Langum, "Discerning Skin: Complexion, Surgery, and Language in Medieval Confession," in Reading Skin in Medieval Culture, ed. Katie L. Walter (New York: Palgrave Macmillan, 2013), 141-160. 
Christ the Physician derives from the material and spiritual instances of healing found in the New Testament. In various miracles, Christ heals blood disease, blindness, leprosy, demonic possession, and paralysis. Christ Himself relates the role of medical healer to the spiritual sickness of sinners. In Mark 2:17: "Non necesse habent sani medico, sed qui male habent : non enim veni vocare justos, sed peccatores" [hole men han no nede to a leche: but pei pat han euele forsope I cam not to clepe iust men: but synneres]." ${ }^{5}$ This image proved highly effective throughout the Middle Ages, particularly in the mandatory confession codified by the reforms of the Third and Fourth Lateran councils. Indeed, the twenty-first canon of the Fourth Lateran Council (1215) preserves one of the most paradigmatic and influential comparisons of priest to doctor who pours wine and oil over the vulneribus "wounds" of the penitent. $^{6}$

Medicine and, specifically, surgery is part of the "discourse community" of later medieval England. Linguists working on the corpus of Middle English medical manuscripts have adopted the concept of "discourse community" in the absence of the precise provenance and lineage of every manuscript and their relationship to other manuscripts. Understood as a group of "people who participate in a set of discourse practices not only by reading and writing, but also by listening," "discourse community" provides a model for how medical texts and concepts might infiltrate other discourses, such as pastoral and devotional works. ${ }^{7}$ The concept of "discourse community" seeks to "explain and define people connected by texts, either as part of their relationships within a particular type of community, or solely by the texts themselves." ${ }^{\prime}$ The idea of a "discourse community," whose members might have varying levels of access

5 Latin Vulgate cited from Clementine Vulgate Project: <http://vulsearch.sourceforge.net/> (accessed 8June 2014); the Middle English is from the Wycliffite version of the Bible. Although the Bible might not have been circulated in all religious contexts, Middle English passages from the Bible were commonly found interspersed in vernacular sermons. The Earlier Version of the Wycliffite Bible, ed. Conrad Lindberg (Stockholm: Almqvist and Wiksell International, 1994). See: James H. Morey, Book and Verse: A Guide to Middle English Biblical Literature (Urbana: University of Illinois Press, 2000).

6 Original Latin text found in Decrees of the Ecumenical Councils, Vol. I Nicaea I to Lateran V, ed. and trans. Norman P. Tanner (London: Sheed and Ward, 1990), 245; translation from Pastors and Care of Souls in Medieval England, ed. John Shinners and William J. Dohar (Notre Dame: University of Notre Dame Press, 1998), 170.

7 Claire Jones, "Discourse Communities and Medical Texts," in Medical and Scientific Writing in Late Medieval English, ed. Païvi Pahta and Irma Taavitsainen (Cambridge: Cambridge University Press, 2004), 23-36, at 24.

8 Jones, “Discourse Communities," 24. 
to medical knowledge and imagery, liberates texts from a "readership" which is largely anachronistic in this period, and allows for a more dynamic understanding of how knowledge is appropriated by broader culture. ${ }^{9}$

There are historical reasons for the growth of more specialized medical imagery in religious contexts. Firstly, the Church subjected the practice of medicine and surgery to growing regulation during this period. After the fourteenth century, penitential manuals place physicians and surgeons under greater scrutiny, listing particular sins attendant to their professions, such as ignorance and rashness, as well as moral quandaries, such as responsibility for death. ${ }^{10}$ While the Fourth Lateran Council explicitly prohibited clergy from practicing incision and cauterization, historians of medicine have argued that the prohibition applied only to secular clergy in major orders and did not exclude surgical operations related to wounds and fractures. ${ }^{11}$ Clerics undoubtedly practiced various forms of medicine in this period. Physicians were often clerics as part of their university education consisted of theology in addition to medicine, and simple parish priests provided a variety of medical services. Carole Rawcliffe's studies reveal that the hospitals of Norfolk were staffed by nuns and priests rather than trained physicians. ${ }^{12}$ Furthermore, Claire Jones's analysis of medieval East Anglian medical manuscripts (mostly from the late fourteenth and early fifteenth centuries) demonstrates that priests owned, and appear to have used, medical texts..$^{13}$ Beyond practice and regulation, clerics were involved in the transmission of medical knowledge, translating and copying medical texts for charity and compassion. ${ }^{14}$ For example, in the early fifteenth-century, a clerk named Austin compiled a medical and surgical compendium in the vernacular "noust to clerkys but to myn

9 Jones, "Discourse Communities," 24. On the general influence of medicine in religious culture in the Middle Ages, see: Joseph Ziegler, Medicine and Religion c. 1300: The Case of Arnau de Vilanova (Oxford: Clarendon Press, 1998).

Darrel W. Amundsen, "Casuistry and the Professional Obligations: the Regulation of Physicians by the Court of Conscience in the Late Middle Ages," Transactions and Studies of the College of Physicians of Philadelphia 3 (1981): 22-37. Darrel W. Amundsen, "Medieval Canon Law on Medical and Surgical Practice by the Clergy," Bulletin of the History of Medicine 52 (1978): 22-44. Carole Rawcliffe, The Hospitals of Medieval Norwich (Norwich: Centre of East Anglian Studies, 1995); Medicine for the Soul: The Life, Death and Resurrection of an England Medieval Hospital, St. Giles, Norwich, c. 1249-1550 (Stroud: Sutton, 1999).

13 M. Claire Jones, "Vernacular Literacy in Late-Medieval England: the Example of East Anglian Medical Manuscripts," (Ph.D. dissertation, University of Glasgow, 2000). 
dere gossip thomas plawdon, citiseyn \& barbour of london" in a "tyme of lakkyng of wise fysicians." ${ }^{15}$

Such clerical translation was part of a larger translation phenomenon of medical and surgical texts into Middle English in the later fourteenth and fifteenth centuries. The electronic database Scientific and Medical Writings in Old and Middle English documents a rise from 200 items in the fourteenth century to 8,00o items in the fifteenth century, which includes both original compositions and translations, many of which are surgical. ${ }^{16}$ Among the native English surgical writers who produced texts are Gilbertus Anglicus (c. 1250), John of Gaddesden (d. 1348), John Arderne (d. 1392) and Thomas Morstede (d. 1450). Gilbertus Anglicus, John of Gaddesden, and John Arderne wrote in Latin, but their texts were translated into Middle English in the late-fourteenth century and fifteenth century. ${ }^{17}$ In addition, many works by continental surgeons circulated in Latin in the fourteenth and fifteenth centuries and were translated into Middle English in the late-fourteenth century and fifteenth century. These include works by Roger Frugard of Salerno (d. 1195), William of Saliceto (d. 1277), Lanfranc of Milan (d. 1306), Henri de Mondeville (d. 1316), and Guy de Chauliac (d. 1368). ${ }^{18}$ Most of the translations date from the fifteenth century; however, Guy de Chauliac's first translation into English dates from shortly

Voigts and McVaugh conjecture that Austin is a clerk, either a cleric or a university man, based on the scholastic vocabulary of the rest of the manuscript. Linda E. Voigts and Michael R. McVaugh, "A Latin Technical Phlebotomy and Its Middle English Translation," Transactions of the American Philosophical Society 74 (1984): 1-69, at 15.

Païvi Pahta and Irma Taavitsainen, "Vernacularisation of Scientific and Medical Writing in Its Sociohistorical Context," in Medical and Scientific Writing in Late Medieval English (Cambridge: Cambridge University Press, 2004), 1-18, at 11. For the electronic database on CDROM, see: Scientific and Medical Writings in Old and Middle English: An Electronic Reference, SEenet, ed. Linda Ehrsam Voigts and Patricia Deery Kurtz (Ann Arbor: University of Michigan Press, 2001).

Getz lists 15 manuscripts dating from the fifteenth century that contain Gilbertus Anglicus's pharmacology. Faye Marie Getz, Healing and Society in Medieval England: A Middle English Translation of the Pharmaceutical Writings of Gilbertus Anglicus (Madison: University of Wisconsin Press, 1991), xii. Robbins lists 11 copies of John Arderne's Practica in Middle English (of which there are four separate translations), the first dating from the late fourteenth century. Rossell Hope Robbins, "Medical Manuscripts in Middle English," Speculum 45 (1970): 393-415, at 406. Peter Murray Jones, "Four Middle English Translations of John of Arderne," in Latin and Vernacular Studies in Late Medieval Manuscripts, ed. A J. Minnis (Cambridge: D.S. Brewer, 1989), 61-89.

Among the most popular surgical texts translated into Middle English are those by Guy de Chauliac, Lanfranc of Milan, and John Arderne. Robbins lists eight extant copies of Lanfranc's surgical manual and seven copies of Guy de Chauliac (of which there are two 
after his death in the fourteenth century. ${ }^{19}$ In addition, numerous, unnamed original and translated texts on particular aspects of surgery, such as bloodletting, were produced in this period. ${ }^{20}$ Although little is known about the translation and production of medical texts in the vernacular, there is evidence of the parallel production of surgical and devotional texts in Middle English beyond the clerical context. Irma Taavitsainen has argued, for example, for the existence of a fifteenth-century scriptorium in the East Midlands that specialized in surgical tracts, including translations of Guy de Chauliac's Chirurgia magna, and religious and devotional treatises. ${ }^{21}$

The audience for these texts is not always clear. Many Latin texts were bequeathed to university faculties, leaving records of ownership. ${ }^{22}$ It is tempting to attribute Middle English copies to non-university educated owners. As is to be expected, some vernacular translations were owned and written for barber-surgeons, such as Plawdon. ${ }^{23}$ However, others appear to have been owned by university-trained physicians. Indeed, Middle English texts are often interleaved with Latin texts in many medical manuscripts. ${ }^{24}$ Furthermore, ownership alone does not guarantee that owners could read and understand the medical text. ${ }^{25}$

complete separate translations and two incomplete translations). Robbins, "Medical Manuscripts," 406.

See: Keiser, George R., A Manual of the Writings in Middle English, 1050-1500 Works of Science and Education (New Haven:Yale University Press, 1998); The Middle English Translation of Guy de Chauliac's Anatomy, ed. Björn Wallner (Lund: cwK Gleerup, 1964), viii.

20 Voigts and McVaugh, "A Latin Technical Phlebotomy," 21-25.

21 Irma Taavitsainen, "Scriptorial 'House Styles' and Discourse Communities," in Medical and Scientific Writing, ed. Tavitsaininen and Pahta, 209-240.

22 Vern L. Bullough, "Duke Humphrey and His Medical Collections," Renaissance News 14 (1961): 87-91.

23 Peter Murray Jones, "Four Middle English Translations of John of Arderne," in Latin and Vernacular: Studies in Late-Medieval Texts and Manuscripts, ed. A.J. Minnis (Cambridge: D.S. Brewer, 1989), 61-89, at 61-62. See also: Claire Jones, "An Assortment of Doctors: the Readers of Medical Books in Late Medieval England," Journal of the Early Book Society 3 (2000): 136-151.

24 Voigts notes that medical writings are more likely to appear in a mixture of Latin and English than in a single language. Many also contain Anglo-Norman texts. See: Linda Ehrsam Voigts, "Scientific and Medical Books," in Book Production and Publishing in Britain 1375-1475, ed. Jeremy Griffiths and Derek Pearsall (Cambridge: Cambridge University Press, 1989), 345-402.

25 Monica H. Green, "Books as a Source of Medical Education for Women in the Middle Ages," Dynamis 20 (2000): 331-69, at 334. 
Nevertheless, historians of medicine have noted that vernacularization facilitated "popular consumption" of medical knowledge beyond the monasteries and universities. ${ }^{26}$ Although there is uncertainty surrounding ownership, audience, and use, there appears to be some general familiarity of surgical and medical practice. Although surgeons such as John Arderne boasted incredibly wealthy clients in his surgical manual, less wealthy Londoners would have been exposed to barber-surgeons, tradespeople who performed a variety of services, such as dentistry, bloodletting, and amputation. By some estimates, there were 1,700 barber surgeons active in England between 1340 and $1511 .{ }^{27}$ Furthermore, surgical procedures, such as bloodletting, would have been performed by other part-time practitioners as well. ${ }^{28}$

Whether or not devotional writers would have access to particular surgical texts, the use of surgery as a metaphor for spiritual practice parallels the vernacularization of learned medicine in the fourteenth and fifteenth centuries. The Middle English Dictionary includes references only from the very late fourteenth century and the fifteenth century where "cirurgien" refers figuratively to "one who heals or cures souls, a healer" in contrast to more pragmatic, literal designations of surgical practitioners. ${ }^{29}$ The introduction of the term "surgeon" as spiritual metaphor in English implies that surgery entered the broader discourse community of medieval England. Furthermore, the availability of texts in Latin and Middle English suggests a wider possibility of dissemination of specific surgical knowledge. Therefore, the relationship of clergy to practice and translation, as well as the concurrent circulation of devotional texts and surgical texts, establishes a particularly English context for what Joseph Ziegler, among others, has identified as the emergence of medicine as a "significant cultural agent." 30

Christ as a surgeon is a potent image given the ambiguous position of the surgeon in medieval society and the extremity and pain of surgical treatment itself. As Patricia Skinner explains in this volume, during the later Middle Ages,

26 Getz, Healing and Society, xvi; Peter Murray Jones, "Medicine and Science," in The Cambridge History of the Book in Britain, vol. 3, ed. Lotte Hellinga and J.B. Trapp (Cambridge: Cambridge University Press, 1999), 433.

27 Nancy G. Siraisi, Medieval and Early Renaissance Medicine: An Introduction to Knowledge and Practice (Chicago: University of Chicago Press, 1990), 24.

28 Faye Getz, Medicine in the English Middle Ages (Princeton: Princeton University Press, 1998), 7-12; Siraisi, Medieval and Early Renaissance Medicine, 24.

29 The Middle English Dictionary <http://quod.lib.umich.edu/cgi/m/mec/med-idx?type=id \&id=MED33414> (accessed 14 November 2013).

$30 \quad$ Ziegler, Medicine and Religion, 177. 
surgery emerged as a separate craft from medicine, at least in theory. ${ }^{31}$ While surgery was practiced in Europe throughout the ancient world and the Middle Ages, it did not achieve "institutional stability" until the thirteenth century. The factors involved in this transition include the translation and circulation of Arabic texts and the greater concentration of populations into urban centers, which fostered universities and apprenticeship structures. ${ }^{32}$ Surgery occupied a particularly debased position in England. In contrast to the Continent, surgery was not studied at all at Oxford or Cambridge, where medicine itself was a minor subject. ${ }^{33}$ Instead, surgery was institutionalized in guilds in England (the earliest established in 1368), which required a university education and provided apprenticeship for practical experience. ${ }^{34}$ After a number of years, surgeons took an exam in order to become masters of surgery. Bryon Grigsby, however, has demonstrated a sharp rise in the number of untrained surgical practitioners between 1350 and $1450 .{ }^{35}$ Hence, educated surgeons, such as Thomas Morstede, along with physicians, petitioned the king in 1421 to forbid the uneducated from practicing medicine. They were particularly concerned about untrained surgical practitioners, such as barbers. ${ }^{36}$

However, beyond practical fears of ignorant practitioners, surgery was deemed intrinsically inferior to medicine due to its tactility. Whereas medicine tended to the theoretical, surgery was more practical, more craft than art. As Guy de Chauliac's surgical manual explains, surgery is a science involving operationes manuum "hande werkes." ${ }^{37}$ When put into English, many surgical texts, such as the fifteenth-century translation of Lanfranc of Milan, provide an etymology of the craft founded on touch, hands, and manual labour: "In

$31 \quad$ Patricia Skinner, "Visible Prowess? Reading Men's Head and Face Wounds in Early Medieval Europe to $1000 \mathrm{CE}$," in this volume, 81-101.

This background is described in the entry on "Surgery," in Medieval Science, Technology and Medicine: An Encyclopedia, ed. Thomas F. Glick, Steven John Livesey, and Faith Wallis (London: Routledge, 2005), 464-467. Knowledge and practice overlapped in the various divisions of medical practitioners, but notions of hierarchical social status are documented by Vern L. Bullough, "Status and Medieval Medicine," Journal of Health and Human Behavior 2 (1961): 204-210 and Siraisi, Medieval and Early Renaissance Medicine, 179 .

33 Voigts and McVaugh, "A Latin Technical Phlebotomy," 13.

34 Bryon Grigsby, “The Social Position of the Surgeon in London, 1350-1450," Essays in Medieval Studies 13 (1996): 71-80, at 75 .

35 Grigsby, "The Social Position of the Surgeon," 75.

36 Grigsby, "The Social Position of the Surgeon," 77.

37 The Middle English Translation of Guy de Chauliac's Anatomy, ed. Björn Wallner (Lund: CWK Gleerup, 1964), 7, 154. Hereafter, page numbers for the Latin text and the Middle English translation are given in parentheses. 
englisch siros is an hand, \& gyros gru, pat is worchinge in englisch / For be ende \& pe profite of syurgie is of hand-wyrchynge." 38 Given the perception of surgeons as inferior to physicians, Christ's role as surgeon is implicitly humble. However, this same cause of social inferiority - the manual aspect of surgery - that allowed penetration into hidden depths of the body and potential cures inaccessible to university medicine, had particular utility for confession. The three "operationes cyrurgicorum ... soluere continuum. Iungere separatum extirpare superfluum" [operacions of cirurgiens ... forto lovse continuale, fforto ioyne separate, and for to cutte a-way superflue] (Anatomy, 8, 155) were applied to the confessor. Surgeons physically accessed the innermost parts of another human being in order to heal, just as confessors delved into the depths of the human soul to offer absolution.

When Christ is the surgeon, He is both wounded and healer of wounds. As Langland writes in Piers Plowman, "though he were wounded with his enemy, to warisshen [heal] hymselue/ And dide hym assaie his surgerie on hem pat sike were." ${ }^{9}$ Seeking out the "sike and synfulle" (16.109) for treatment while He himself is wounded, makes Christ the surgeon co-passionate, co-suffering with sinners. Christ's wounds were aligned with particular human sins in sermons; e.g., the crown of thorns with pride. ${ }^{40}$ However, used as an image of compassion - of shared vulnerability, woundedness - rather than confession, surgery also contains the idea of "ioyning" or stitching together a wound in finishing the surgical operation inside the interior.

In essence, a wound is "solucion continuitatis recens sanguinolenta sine putrefaccione in partibus mollibus facta" [solucion [break] of continuite, recent, sanguinolent, without putrefaccioun, made in softe partie3] (Anatomy, 5,57 ) that surgeons must repair through vnicione "onyng" (Anatomy, 81, 85). As a devotional image, then, Christ the surgeon restores "continuite" by knitting together the faithful's wound (caused by original sin and their particular sins) to His own wounded body. The "operacions of cirurgiens" are present in the fifteenth-century Middle English translation of Bridget of Sweden's Liber celestis, in which Christ operates upon the faithful and Himself in one body. In distinction from the Latin text, which was produced for the canonization

38 Lanfrank's "Science of Cirurgie," ed. Robert von Fleischhacker, EETs o.s. 102 (London: Kegan Paul, Trench, Trübner, 1894), 7.

39 William Langland, The Vision of Piers Plowman, ed. A.V.C. Schmidt (London: Dent, 1995), 16.105-106.

40

Holly Johnson, "A Fifteenth-Century Sermon Enacts the Seven Deadly Sins," in Sin in Medieval and Early Modern Culture: The Tradition of the Seven Deadly Sins, ed. Richard Newhauser and Susan J. Ridyard (York: York Medieval Press, 2012), 107-131, at 108. 
process in 1377, the Middle English translation specifically identifies Christ as surgeon. In a vision, Christ demonstrates how he "cuttes away rotyn fleshe and transform [e]s" the faithful "vnto hymselfe." The metaphor elaborates upon the corporate body of Christ:

My frendes are as my arme, in pe whilke are fyfe pinges. pe first is pe skyn, pan fleshe, blode, bone and mergh [marrow]. Bot I do as a surgen pat cuttes away all pat is dede. So I take away fro my frendes pe worldly coueytise and lustes of fleshe, and I putt to pame helpe of my myght, as it were mergh, for ryght as wythouten mergh is no strengh in pe arme, right so wythouten my might is mannes might nozt. And pis mergh is in pe bone pat is sade. So sall my frendes knaw my myght and besy pam to wirke pe gude wyth a lastyng will. pe third is pe blode, pat bytokens a gude will; and pe fleshe paciens, pat is softe of pe selfe; and pe skyn bytokens lufe, in token pat pai suld lufe nopinge so mykyll as me. And pan I knyt pam fulli to myselfe, and hase pame all in me.41

Here, the text draws upon the conventional image of the corporate body of Christ and the incisive penetration of the word of God which "vivus est enim sermo Dei, et efficax et penetrabilior omni gladio ancipiti : et pertingens usque ad divisionem animæ ac spiritus : compagum quoque ac medullarum, et discretor cogitationum et intentionum cordis" [forsope pe wrd of god is quik \& spedi in wirking \& more able to persen pan alle twei eggid swerd \& entrende til to departing of soule \& sperit \& ioyntures \& Merewis \& departere of tho3tis \& intenciouns of hertes]. ${ }^{42}$ While Bridget's Latin text portrays an almost identical image of the Middle English, Christ is simply medicus not chirurgus. ${ }^{43}$

The alteration of Christ from medicus in the fourteenth-century Latin text to "surgen" in the fifteenth-century Middle English text suggests a growing familiarity with surgery in medieval England, thus inviting comparison with contemporary surgical practice. What might the operation described, the

The Liber Celestis of St. Bridget of Sweden, ed. R. Ellis, EETS 0.s. 291 (London: Oxford University Press, 1987), 334. The Latin is found at <http://riksarkivet.se/crb > (accessed 14 November 2013), Bk. 4, 9o. Where relevant, page numbers will be given in parentheses. Hebrews 4:12. Latin at <http://vulsearch.sourceforge.net/> (accessed 14 November 2013) and Middle English from The Earlier Version of the Wycliffite Bible, vol. 8. but as "läkiare" [doctor]; however, He does performs a surgical procedure, cutting off what is unhealthy from the body. Professor Jonas Carlquist has suggested to me that there was not a distinct word for "surgeon" in Old Swedish. Heliga Birgittas Uppenbarelser, ed. G.E. Klemming (Stockholm: P.A. Norstedt and Sons, 1860), Bk. 2.175. 
removal of dead flesh and the infusion of marrow, mean in surgical terms? In general, medieval medicine thought marrow strengthened and moistened bones and "virtutem animalis nutrit et conseruat" [fedip, norischip, and sauep pe vertue of felinge]. ${ }^{44}$ Given this critical importance for the body, many surgical texts expressly warn surgeons against making deep incisions lest they allow the marrow to escape and their patients die. Speaking of such a wound, Guy de Chauliac warns of great incisions where "exeat medulla est periculosa \& vt plurimum mortificans membrum" [be merowe go out ... is perilous \& oftentyme3 mortifying pe membre]. ${ }^{45}$ In surgical terms, Christ performs a perilous operation on Himself to strengthen mankind.

Furthermore, the two properties of marrow - moistening and "felinge" - are significant to medieval understandings of compassion. "Felinge," also called the spiritus animalis "the vital spirit," described the substance in the brain and nervous system responsible for movement and perception (3.22). Furthermore, "the moystnes of pyte" or "moysture of charyte" that softens the heart towards others or God is a common metaphor in medieval sermons and pastoral texts, creating a physiology for compassion. ${ }^{46}$ Just as certain natural dispositions inclined people to particular sins, others inclined to particular virtues. ${ }^{47}$ Dryness, which was thought to occur as the body aged, facilitated the opposing vices of compassion and pity: envy and greed. For example, the homilist of a late-fifteenth century sermon cycle compares the decline of man with the decline of "pite and compassion," a physiologically sound argument in terms of the natural drying of the body with age. ${ }^{48}$ Women, however, were associated

44 Latin text from Bartholomaeus Anglicus, De proprietatibus rerum (Köln: Johan Koelhoff, 1483), 5.58. Middle English from Bartholomaeus Anglicus, On the Properties of Things:John Trevisa's Translation of Bartholomaeus Anglicus De proprietatibus rerum: A Critical Text, ed. M.C. Seymour et al., 3 vols. (Oxford: Clarendon Press, 1975-88), 1: Bk. 5, 58. Hereafter, book and page numbers are given in parentheses in the text.

The Middle English Translation of Guy de Chauliac's Treatise on Wounds, ed. Björn Wallner (Lund: cwK Gleerup, 1976), English in Part 1,9o; Latin in Part 2.88. Hereafter, part and page numbers are given in parentheses.

46 The first quotation is from A Late Fifteenth-Century Dominical Sermon Cycle, vol. 1, ed. Stephen Morrison, EETS o.s. 337, 338 (Oxford: Oxford University Press, 2012), 61-2. The second is from The Middle English Mirror, ed. Kathleen Marie Blumreich (Tempe: Arizona Center for Medieval and Renaissance Studies, 2002), 103. See also: Ziegler, Medicine and Religion, 294.

47 Joseph Ziegler, "The Biology of the Virtues," in Im Korsett der Tugenden, ed. Mariacarla Gadebusch Bondio and Andrea Bettels (Hildesheim: Olms, 2013), 3-23, at 8.

48 Dominical Sermon Cycle, 63. For the drying of the body with age, see: Shulamith Shahar, Growing Old in the Middle Ages: "Winter Clothes Us in Shadow and Pain" (London: Routledge, 1997), 70. De proprietatibus rerum, chaps. 4, 3 . 
with moisture. Scholars have examined how female writers reinscribe the excess moisture and other physiological attributes disparaged by moralists as a quality that enables their receptivity and compassion. If dryness kept the body closed and intact, the bodily instability inherent in moistness in a devotional context enabled the believer to join Christ. ${ }^{49}$ Surgical knowledge provides another dimension to this devotional physiology. Paradoxically, the moistness both caused a natural lack of "continuite" and allowed healing. According to Guy de Chauliac: "in infantibus autem \& mulieribus vidi consolidari arteriam propter humiditatem \& molliciem corporis" [in enfante3, forsop, \& in wymmen y haue sene an arterie consolded for moistne 3 \& softnes of be body] (Treatise on Wounds 1.18; 2.62). Christ's operation, as described in the Middle English translation of Bridget, bolsters the spiritual and physical health of the open wound. However, Christ is not merely the surgeon; He is also the surgical patient here. As "wounded surgeon," he embodies compassion, suffering together.

Compassion is both a meditative aid and a medical principle in the later Middle Ages. Bridget connects the suffering of one part of the body with another by a medical, and, in the Middle English version, specifically surgical metaphor. In the Bible, Paul develops bodily metaphors of suffering and compassion. For example, in 1 Corinthians 12:26-7: "et si quid patitur unum membrum, compatiuntur omnia membra: sive gloriatur unum membrum, congaudent omnia membra. Vos autem estis corpus Christi, et membra de membro" [if o membre suffre eny thing: alle membris suffrin perwip eiper if o membre gloriep: alle membris iozen togidere. Forsope zee ben pe bodi o crist and membris of membris]..$^{50}$ In patristic theology, the faithful become members of the body of the Church and of Christ by participating in the sacraments. Wounded limbs or members threaten the corporate body and must be healed or amputated. ${ }^{51}$ In this tradition, pastoral texts invoke the wounded limb to

49 See: Nancy Caciola, Discerning Spirits: Divine and Demonic Possession in the Middle Ages (Ithaca, NY: Cornell University Press, 2003); Elizabeth Robertson, "Medieval Medical View of Women and Female Spirituality in the Ancrene Wisse and Julian of Norwich's Showings," in Feminist Approaches to the Body in Medieval Literature, ed. Lisa Lomperis and Sarah Stanbury (Philadelphia: University of Pennsylvania Press, 1993), 142-167.

50 Latin Vulgate <http://vulsearch.sourceforge.net/> (accessed 14 Nov. 2013) and The Earlier Version of the Wycliffite Bible.

51 See for example: Augustine, De doctrina christiana, CCsL 32, I.xvi.15 (Turnhout: Brepols, 1962), ed. Joseph Martin, as well as those examples cited from Augustine, see those by John Chrysostom and Jerome in Leanne Groeneveld, "Salvation, Damnation, and the Wounded (Corporate) Body of Christ in Late Medieval Culture," Florilegium 22 (2005): $86-90$. 
urge correction and punishment. While these analogies derive from an old tradition, the association of physical with emotional pain, specifically the compassion felt for wounds by other parts of the body and other bodies entirely, reflects newer medical knowledge, or at least the circulation thereof in the later Middle Ages.

"Compaciens" or compassion as understood by medieval medicine referred to how parts of the body felt pain or suffered with other parts of the body. As Bartholomaeus Anglicus writes in his influential encyclopedia De proprietatibus rerum (c. 1240-1250), that was translated into English by John Trevisa in the late fourteenth century and exists in numerous copies, the members of the body mutuo compatiuntur "hap compaciens of opir" because of their inuicem colligantiam "be byndinge and knettinge togedres" (5.1). Therefore, "unde memborum minus patiens condolet amplius patienti" [be membre lesse igreued hap compaciens of pe membre pat is more igreued] (5.1). Bartholomaeus describes this compassion as the movement of humors from other parts of the body to the locus doloris "be sore place" (5.1).

Surgical texts also consider parts of the body that have colligantiam magnam "grete colligance" with each other, such as the womb with the brain, heart, liver and stomach, and the bladder with the anus, meaning that when one part suffers, those other parts se compatiuntur or "bene pame selfe compacientez togidre" (Anatomy 138, 201). Likewise, in his treatise on wounds, Guy de Chauliac discusses cerebri compassionis "spasme 3 ... of be brayne compassioun" and spasmi ... compassiui "spasme compassiue" when the brain responds to wounds in other parts of the body (Treatise on Wounds 1.40, 42; 2.69-70). This physical understanding of compassion was not simply copied from the Latin but was re-iterated in original and influential contexts. For example, the Middle English translation of surgeon Gilbertus Anglicus's pharmacology, preserved in at least fifteen fifteenth-century copies, inserts a description of the "compassion" felt by the heart for pains in the stomach that is not found in the Latin exemplar. ${ }^{2}$

Scholastic discussions of the soul's sensation of pain reinforced the somatic understanding of compassion found in surgical and medical texts. As Esther Cohen discusses in her seminal work on pain in the Middle Ages, later medieval thought developed an understanding of pain attendant upon "interior sensation, rather than an exterior trauma. ${ }^{53}$ In discussing the surgical procedure of cauterization, the theologian Duns Scots, for example, argued that the

$5^{2}$ Getz, Healing and Society, 144, 301 n. 144/3.

53 Esther Cohen, The Modulated Scream: Pain in Late Medieval Culture (Chicago: University of Chicago Press, 2009), 258. 
thought of the procedure was enough to induce the sensation of pain in the body. ${ }^{54}$ Thus, imagining physical pain is a way of experiencing physical pain. Furthermore, as a similar example of the compassio and colligantia described above in Guy de Chauliac, the surgeon Henri de Mondeville, whose surgical works were circulated in the original Latin and translated into Middle English, also explains how "syncope" or "swooning" can occur in healthy men who see surgical operations. ${ }^{5}$

This medical context for compassionate pain enriches readings of devotional descriptions of Christ's wounds. The late fourteenth-century Julian of Norwich, for example, begins her Revelation of Love, the earliest manuscript of which dates from the first quarter of the fifteenth century, with a desire for bodily affliction "for I would that his peynes were my peynes with compassion." 56 Specifically, she petitions Christ for three graces: "mende of his passion ... bodily sekenese ... iii wounds" (2). The three wounds she explains are the wounds of contrition, "the wounde of kinde compassion," and the wound of longing for God (3). Julian explicitly links wounds and compassion at the outset of her text in her desire for spiritual stigmata. ${ }^{57}$ She is ultimately granted these petitions through her own experience of illness and suffering. As one modern reader notes that "although it may be felt as a wounding it is, in fact, a healing surgery." ${ }^{58}$ While it is uncertain what specific surgical knowledge Julian would have accessed, she would have likely been familiar with bloodletting at the very least. Bloodletting was part of the regimen in the monasteries and anchorholds. ${ }^{59}$

54 Cohen, The Modulated Scream, 107.

55 Latin text cited by Marie-Christine Pouchelle, The Body and Surgery in the Middle Ages (Oxford: Polity, 1990), 115. Middle English version found in Richard Grothé, "Le Ms. Wellcome 564 Deux Traites de Chirurgie en Moyen-Anglais," (Ph.D. dissertation, University of Montreal, 1982).

56 Julian of Norwich, A Revelation of Love, ed. Marion Glasscoe (Exeter: Exeter University Press, 1993), 5. Hereafter, page numbers are given in parentheses.

57 While there were occurrences of stigmatics on the continent during the period, this sort of compassionate wounding appears to have been solely metaphorical in medieval England. Most examples of contemporary stigmatics are Italian women. See: Gábor Klaniczay, "On the Stigmatization of Saint Margaret of Hungary," in Medieval Christianity in Practice, ed. Miri Rubin (Princeton: Princeton University Press, 2009), 265-73; and Katharine Park, Secrets of Women: Gender, Generation, and the Origins of Human Dissection (New York: Zone Books, 2006).

58 Marion Glasscoe, English Medieval Mystics: Games of Faith (London: Longman, 1993), 216.

59 Ancrene Wisse, for example, provides guidelines for bloodletting. Anchoritic Spirituality: Ancrene Wisse and Associated Work, ed. Anne Savage and Nicholas Watson (New York: Paulist Press, 1991), 204. M.K.K. Yearl, "Medieval Monastic Customaries on Minuti and 
In Julian's account of her illness and simultaneous vision of the crucified Christ, her own pain and blood mingle with Christ's bloody wounds so they are indistinguishable. They are co-passionate in material and symbolic terms. Ultimately, Julian's vision of compassionate suffering expands even beyond herself and Christ. She takes a conventional image meant to spur private confession - Christ's side wound - and expands it so it is "large enow for al mankynd" (35). ${ }^{60}$ Looking into His side wound, Christ "beheld enioyande; and with his swete lokyng he led forth the understondyng of his creature by the same wound into his syde withinne" (35). In this passage, "enioyand" assonates with "joining" and the sense of closing a wound in surgical practice, so that the faithful are "joined" or sewn to His wound, flesh to flesh.

The side wound found in the Middle English translation of Bridget of Sweden's Liber celestis further breaks down discrete identities in the crucifixion scene. From Mary's point of view, "right as pat pinge pat is halfe within and halfe withoute, if pe part withoute be prikked, als mikill paine felis pe parte pat is within, right so when mi son was scourged and prikked, it was to me as mine awen hert had bene scourged and prikked" (63). ${ }^{61}$ A string of dependent clauses makes it difficult to distinguish between Mary and Jesus. For example, in the phrase "when he loked fro pe crosse to me and I to him, pan went pe teres oute of mi eyn as blode oute of vainnes," it is unclear whether Christ's blood is running out of His veins at the same time "as" tears run out of Mary's eyes, or if Mary's tears are pouring out of her eyes figuratively as blood flows out of veins (63). ${ }^{62}$ The passage progresses with syntactical torture: "when he saw me in pat sorowe, it encresid so his sorowe pat pe sorowe of his awen woundes were noght allmoste felid, for pe paine he had of pe sorowe he saw in me" (63). However, the passage resolves itself with Mary speaking "plainli" in "his sorowe was mi sorowe, for his hert was mi hert" (63). This reversion back

Infirmi," in The Medieval Hospital and Medical Practice, ed. Barbara S. Bowers (Burlington, VT: Ashgate, 2007), 175-194.

6o In this exemplum type, Christ appears to unconfessed sinners and invites them to touch His side wound. Afterwards, the sinners' hands are stained with blood until confessed. Printed exempla of this theme are catalogued by Frederic C. Tubach, Index exemplorum: a Handbook of Medieval Religious Tales (Helsinki: Suamalainen Tiedeakatemia, 1969), 191. For a contemporary Middle English example, see: The Early English Versions of the Gesta Romanorum, ed. Sidney J.H. Herrtage, EETs e.s. 33 (London: Oxford University Press, 1879), 393 .

61 The Middle English follows the Latin closely, which is found at $<$ http://riksarkivet.se/crb $>$ (accessed 14 November 2014) Bk. 1, 35 .

62 The Latin quasi does not convey the same ambiguity, suggesting only a resemblance, not a simultaneous event. 
to "plain" speech and grammar emphasizes the complexity and indivisibility of their relationship. This vision of compassion, wherein Mary feels Christ's "membres were to me as mine awen membres, and as my own hert" where the pain of Christ's "woundes" is deferred to Mary's heart evokes the "compassion" felt by the heart in medical contexts (Liber celestis 63). Jesus and Mary are copassionate bodies through Christ's wounds.

Implicit in Julian and Bridget's accounts of Christ's wounds, however, is that the reader will also experience compassion. Circumcision narratives make the connection between the imagination of Christ's wounds and pain with the compassion of the reader more explicit. In circumcision narratives, Christ functions as "wounded surgeon," healing through His own wound. Although established in the mid-sixth century, the feast of the circumcision became a popular subject of vernacular narratives and imagery in the late fourteenth century and fifteenth century. ${ }^{63}$ Leo Steinberg has argued that this surge in interest in the circumcision is likely due to its inclusion in two widely circulated texts of the later Middle Ages. ${ }^{64}$

As recapitulated in numerous sermons and devotional passages, the circumcision is the initial wound which Christ suffers for human health, which prefigures all the other wounds He will suffer later. It is also the only surgical wound as such that He suffers, and these texts generate compassion through reflection upon the infant's wound as both material and symbolic. A late medieval English audience would not have been familiar with the surgical procedure. As part of the Old Law, circumcision was considered superfluous and sinful for Christians. Theologians, such as Thomas Aquinas and Duns Scotus, claimed circumcision to be a mortal sin, and the Council of Florence (1442) declared circumcision a barrier to salvation. ${ }^{65}$ Furthermore, the Jews were expelled from England in 1290 and not readmitted until 1656 . Surgical writers offer little judg-

63 The feast was officially removed from the church calendar in 1960 in the Second Vatican Council.

64 These texts are the pseudo-Bonaventuran Meditations on the Life of Christ, translated by Nicholas Love as The Mirror of the Blessed Life of Jesus Christ in Middle English, and Jacobus de Voragine's thirteenth-century Legenda Aurea (1255-1266), both used by homilists and devotional writers in their compilations and translated in 1438 as the Gilte Legende in Middle English. See: Leo Steinberg, The Sexuality of Christ in Renaissance Art and in Modern Oblivion (Chicago: University of Chicago Press, 1996), 50, 56-7; Nicholas Love, The Mirror of the Blessed Life of Jesus Christ: A Reading Text, ed. Michael G. Sargent (Exeter: Exeter University Press, 2004); Gilte Legende, ed. Richard Hamer, EETS o.s. 327, 328 (Oxford: Oxford University Press, 2006).

65 Irven M. Resnick, Marks of Distinctions: Christian Perceptions of Jews in the High Middle Ages (Washington, D.C.: Catholic University of America Press, 2012), 54-55. 
ment or description of the issue. Guy de Chauliac includes a rare but perfunctory explanation in the antidotary to his surgical manual:

circuncisio secundum legemsit iudeis \& saracensis \& aliis que multi est vtilis; propterea quod non congregantur sordities in radice balani \& calefacerent ipsum. Et tunc cum vnguibus trahatur preputium quam tum erit possibile \& cauendo de balano incidatur. \& post cum pulueribus ru. aut cum cauterio sanguis restringatur \& more aliorum vlcerum sanetur. ${ }^{66}$

[circumcicioun is made after be lawe to Iewes and Sarasenes, and to many opere it were able, for pat filpes schulde be gadrede togidre in pe rote of pe knoppe of be zerde [penis] and schulde chaufe it. And pan be it drawen with pi nayles as mykel as it is possible, and in eschewynge of pe knoppe, kytte it. And afterwarde be pe blode restreyned with pe rede powdre or with a cauterie, and hele it in pe maner of oper woundes]. ${ }^{67}$

Likewise, the operation itself is rarely discussed in vernacular descriptions of Christ's circumcision. A rare example occurs in a fifteenth-century collection of Lollard sermons which explains the context and practice as "a ryte and a religioun in Old Lawe, comaundid to pe chyldren of Israel, pat in pe eytepe dai aftur bat a chyld were born pei shulden kutte away a lytel garland round aboute of pe vttermure part of pe skyn of his 3erde." 68 However, most writers do not detail the material operation.

Instead, writers emphasize the pain of the experience. While for centuries, theologians such as Ambrose and Bede had prefigured the crucifixion in the circumcision, details about His pain surfaced in the fourteenth century in continental texts and appear with frequency in texts from the fifteenth century in medieval England. ${ }^{69}$ As with Christ's crucifixion, the pain described in circumcision accounts would seem to contrast with the greater majority of iconographic representations of a smiling or expressionless Christ. ${ }^{70}$ In

66 Guidonis de Cauliaco, Chyrurgia Guidonis de Cauliaco (Lugduni: Vincentius de Portonariis, 1537), f. 259r.

67 Cyrurgie of Guy de Chauliac, ed. Margaret Ogden, EETS o.s. 265 (Oxford: Oxford University Press, 1971), 528-529.

68 Lollard Sermons, ed. Gloria Cigman, EETs o.s. 294 (Oxford: Oxford University Press, 1989), 66 .

69 See: Steinberg, The Sexuality of Christ, 156; Cohen, Modulated Scream, 223.

70 Depictions, all late medieval, of a distressed Christ-child are mentioned by Henry Abramson and Carrie Hannon in "Depicting the Ambiguous Wound," in The Covenant of 
medieval England, the circumcision was a rare choice for visual representation. Devotional texts, however, articulate how the pain of the event affirms Christ's full humanity. For example, Speculum devotorum, a meditative prose life of Christ dating from the first quarter of the fifteenth century, writes that "he hadde perfitely taken mankynde, in no wyse leuynge pe kynde of God, in pe whiche he is euermore euen to pe fadre."71 Thus, "he sufferede full myche payne in our kynde, pe whiche is impassible in his owne, and so he suffered in his circumcisioun full mykell payne and haue pite and compassioun of hym" (102). The writer accentuates the "full grete peyne" "done in a ful tendere place of a mannes body with a knyfe" (Speculum devotorum 102).

Furthermore, the pain felt by Jesus is enhanced by His physiology and age. Medieval medicine held that the more balanced a person's complexion, the more highly developed the senses. Thus, theologians such as Alexander of Hales argued that Jesus, with His perfect complexion, felt pain more acutely.72 So whereas Bridget's Christ as surgeon supplies healing moisture from His own body, at the Crucifixion He suffers: "he toke mi fleshe pe clenneste bodi and best complexiond" which causes "an vntrowabill sorowe and passion" (21). Further details related to Christ's body, particularly His age and young flesh, help the faithful to imagine and suffer his pain co-passionately. Thus, Speculum devotorum urges "haueth pyte and compassioun to se pat feyre tender childe and youre louely Lorde yputte to so grete peyne so yonge. And also yhe may thenke pat for peyne of pat kyttynge he wepeth and cryeth, as pe maner of children is" (102). The soft and tender skin corresponds with the unhardened body of the infant as described in medical texts (De proprietatibus rerum 6.4). In Mirror of the Blessed Life, Nicholas Love takes the detail to reaffirm Christ's humanity and pain,

his tendere flesh was kut, with a sharp stonen knife, \& so pat zonge child Jesus kyndly wept for pe sorow pat he felt perporh in his flesh. For

Circumcision: New Perspectives on an Ancient Jewish Rite, ed. Elizabeth Wyner Mark (Hanover: Brandeis University Press, 2003), 98-113, 107-109. Representations in England, however, are expressionless. Visual representations of the circumcision from medieval England are noted by Linda Bates: The East window at St. Peter Mancroft, a gold triptych found in Campion Hall, Oxford and roof bosses found in Norwich Cathedral, and in the Church of St. Peter and St. Paul, Salle. Bates, "Christ's Birth and Infancy in Middle English" (Ph.D. dissertation, Cambridge University, 2011) 98.

71 "Myrror to Devout People (Speculum devotorum): an Edition with Commentary," ed. Paul J. Patterson (Ph.D. dissertation, University of Notre Dame, 2006), 102. Page numbers are given in parentheses.

72 Cohen, Modulated Scream, 205. 
without doute he hade verrey flesh \& kyndly suffrable as haue oper children. Shold we pan not haue compassion of him (42).

Love intermingles the reader's thoughts with the details of the scene, encouraging compassion.

In her treatment of Love's crucifixion passage, Sarah McNamer argues that his use of the word "beholde" functions "as a mechanism for generating sensory perception itself: for generating a specific way of seeing ... that had the potential for producing - in the body, as well as in the mind - an impulse toward a particular form of compassion: the protective and ameliorative action of holding."73 Although the word "beholde" does not occur in the circumcision passage, the passage describing the weeping child evokes this idea. Where Mary holds the child in her "barme," she ultimately receives comfort from Him:

when she sey hir louely sone wepe: she mizt not withhold wepyng, \& pan mowe we ymagine \& penk how pat litel babe in his modere barme seynge hir wepe, put his litel hande to hire face, als he wold pat she shold not wepe, \& she azeynward inwardly stired \& hauyng compassion of pe sorowe \& pe wepyng of hir dere son, with kissyng \& spekyng, comforted him as she mizt, for she vndurstode wele by pe inspiracion of pe holi gost pat was in hire pe wille of his son, pouh he speke not to hir (42).

Mary, in turn, asks Him to cease His weeping, as it is the cause of hers: "so porh pe compassion of pe modere, pe child sesed of sobbyng \& wepyng" (42). Their mutual physical and emotional suffering enables silent communication, facilitated by the proximity of their bodies and their pain. The faithful, who "ymagine \& penk" of the mother and the child's pain, are also folded into this process.

Reflection upon the material surgical event and its attendant physical and emotional pain invariably leads to an exegetical treatment of the surgical event as metaphor in which Christ's wound becomes an occasion for the faithful to consider their own wounds. Christ's surgery becomes an invitation for the faithful to undergo their own surgery. As Love explains, "we sholen haue gostly circumcision, pat is kuttyng awey fro vs al superflue pinges pat disposen to synne, \& haldyng with vs as in affection oneliche pat is nedfull to vertues lyuyng" (43). To this end, the faithful must exercise "gostly circumcision" on their five senses, and take care to remove what is most superfluous, in particu- 
lar, speech, echoing Augustine's famous injunction for God to circumcise his lips (43).

Given the location of Christ's wound, other sermons, such as that found in the fifteenth-century Lollard collection, focus on sins of "lecherie" deriving from "bat membre in whiche men fynden most stirynge to pat synne" (Lollard Sermons, 70). Christ's circumcision is taken as an example of "clannesse and chastite" to encourage believers to refrain from "al maner of lecher in poust, word, and dede" (70). Speculum devotorum admonishes "circmcideth yourselfe for his loue, bothe bodily and gostely" (103). The terms "bodily" or "outwarde circumcisioun" signify habit, deeds, and words rather than surgical circumcision. By "inwarde" circumcision, the author refers to thought, affection, and intention (103). Likewise, the author of the fifteenth-century Speculum sacerdotale emphasizes the metaphorical utility of Christ's operation: "Crist was not cicumcised for eny nede but for signyficacion, for that circumcision is nozt symple ne meene. And ry3t as he was cicumcised bodily, rightso he commaundeth and wold vsto be circumcised fleschely and spiritually."74 It is untenable that this writer would have advocated surgical circumcision; however, he does not explicitly state what he means to be circumcised "fleschely." Nevertheless, the emphasis upon "bodily," "outward," and "fleschely" circumcision suggest reflection upon physical pain and the possibility for mutual suffering.

At its most metaphorical, circumcision represents the sacrament of confession, thus the incision is not preventative as above but curative. Just as Jews "weren bounden to bodili circumcision in pe Olde Lawe ... a peyneful kuttynge awei of here flesch ... so cristen men [bep bounde] to gostli circumcisision in pe Newe Lawe ... a peyneful kuttynge awei of al maner of synne poru verrei penance doynge. ..." (Lollard Sermons, 72-3). Just as the rite of circumcision is administered on the eighth day after birth, "gostli circumcision" is to be performed on the eighth "gostli dai" of preparation for the sacrament of confession. The homilist then enumerates "days" or steps for this preparation: sorrow for sin, abomination of sin, the will never to turn again to sin, true confession of sin, holy fasting, devout prayer, and charitable alms. Only after accomplishing these tasks is the sinner capable of being "circumcidid gostli - pat is, to be clansed of alle maner of synne" (73).

Ultimately, circumcision is a prefiguration for the ultimate pain of the crucifixion, and, therefore, an initial treatment for the wound of sin: "here he [schedde] firste his preciouse blode for pe helthe of mankynde" (Speculum devotorum, 103). Many sermons emphasize the shedding of Christ's blood as a 
continuous healing process. Christ is thought to have shed his blood for man five times in the course of his life: "the blode of Criste was schede be effucion. For that [day] ... he schede firste hys sakerd bloode for vs." The circumcision marks the first time, "the begynnyng of owre redempcion" (Dominical Sermon Cycle, 37). "Effucion" serves a dual purpose, referring both to Christ's bloodshed in its primary meaning but also to the application of a liquid or the bathing of a wound. In Guy de Chauliac's surgery: "et fortasse inscicioni succedunt dolor \& punctura quare opportet vt administretur effusio olei anetini aut camomillini" [and peraunetour to incision come-to aking \& puncture, wherfor it bihouep pat per be minstered effusioun of olei anetini or camomille vp-on pe puncture] (Treatise on Wounds 1.90; 2.111). Thus, in this secondary surgical sense, Christ, with His own physical wound, ministers to the metaphorical wounds of the faithful. Likewise, Love frames the bleeding wound of the infant Christ as punishment for sin: "pis day oure lord Jesus began to shede his preciouse blode for oure sake. He began betyme to suffre for vs, \& he pat neuer did synne. began pis day to bere payne in his swete tendire body for oure synne" (Mirror of the Blessed Life, 42). Noting that the circumcision marks when Christ "began" to shed His blood, the text foreshadows the greater bloodshed of the crucifixion. Attendant within all discussions of the sacrifice and pain of the circumcision is that it is not enough to heal the wounds of humanity. As the fifteenth-century Tretyse of Loue explains, "pe blode that he lefte thanne of his tender bodi in the cyrcumcysion ne were we not yette enterli helede, for we hadde the meselry [leprosy] of synne, whereof we were so ful of synne \& inpostumys [abscesses] that our sowle was all full of hedowys matyr \& venymous." 75

Thus, a more radical surgical operation is described in a sermon found in a macaronic (with Latin and English blending into each other) sermon preserved in the fifteenth-century Oxford sermon collection Bodley $649 .{ }^{76}$ Here, an extended surgical metaphor describes how the crucified Christ cures the heritage of Adam's sinfulness. Christ is both surgeon and surgical patient in the sermon. First, He takes the pulse and diagnoses the ailment of mankind. Then, He prescribes a diet of spiritual food. Finally, He makes an ointment by crushing His own body against the wood of the cross and laying it against the wound of sin: "his senues and his ioyntis burstoun a too, and fro pe hede to pe fote was no hol pece on him" (Macaronic Sermon, 448). Despite His open wounds, He continues His practice: "pis floure he temprid with pe blode and pe water pat

75 The Tretyse of Loue, ed. John H. Fisher, EETs o.s. 223 (London: Oxford University Press, 1951), 34 .

76 A Macaronic Sermon Collection from Late Medieval England: Oxford Bodley 649, ed. and trans. Patrick J. Horner (Toronto: Pontifical Institute of Mediaeval Studies, 2006). 
ran out de latere suo [of his side], and pariter in igne passionis sue. [as well as in the fire of his passion]. pis emplastre he laide lateri humano pro vlcere peccati. [on the human side for the ulcer of sin]" (448). Here, Christ's body is physically ripped apart for finali sanacione "complete healing" (448). This breaking asunder, this annihilating of the body's "continuite," is a drastic image, as, indeed, surgery was also explained as a drastic and last option in professional texts. It is the third or last option of treatment, after dietare et farmacare "diete and farmacye;" name sine istis non perficitur cyrurgia "withouten pise is no3t cirurgie parfourmed" (Anatomy, 25-26, 161). However, Christ makes His own medicine by breaking His own body so that material dissolution might heal moral dissolution.

In devotional images and in surgical texts, wounds and surgery both cause the discontinuity and repair the integrity of the sinner's body while leaving the body of Christ "open" for continuous meditation and compassion: "sopely in pe wondes of Jesu, zee pe wondes not closed, bot opun \& wide to entre inn" (Mirror of the Blessed Life, 12). By providing an affective metaphorical and physiological framework for compassion, surgery serves a function in the "invention of compassion" discussed recently in the history of emotions. ${ }^{77}$ Through His experience of pain, Christ teaches, or induces, "felinge" in His followers. The excruciating pain of wounding and separating experienced before healing and joining is elegantly expressed in the late medieval conception of Christ "the wounded surgeon." 